\title{
MONO+KM: Knowledge Management in Collaborative Project Development ${ }^{1}$ MONO+KM: administración de conocimiento en el manejo de proyectos colaborativos ${ }^{2}$
}

\author{
Oscar González-Rojas ${ }^{3}$ \\ Gilberto Pedraza-García ${ }^{4}$ \\ Darío Correal \\ Guillermo Beltrán 6
}

doi:10.11144/Javeriana.iyu20-2.mkkm

How to cite this article:

0. González-Rojas, G. Pedraza-García, D. Correal, and G. Beltrán, "MONO+KM: Knowledge management in collaborative project development," Ing. Univ., vol. 20, no. 2, pp. 267-302, 2016. http://dx.doi.org/10.11144/Javeriana.iyu20-2.mkkm

\footnotetext{
'Scientific and technological research article. Submitted on: November $21^{\text {th }}$, 2015. Accepted on: April $13^{\text {th }}$, 2016. This article is derived from the MONO project in the context of the DAVID research project (Strategic Programme for the Research and Development of the Colombian Animation and Video Games Industry).

${ }^{2}$ Artículo de investigación científıca y tecnológica. Fecha de recepción: 21 de noviembre de 2015. Fecha de aceptación: 13 de abril de 2016. Este artículo se deriva del proyecto MONO en el contexto del proyecto de investigación DAVID (Programa Estratégico para la Investigación y Desarrollo de la Industria Colombiana de Animación y Videojuegos).

${ }^{3}$ Ingeniero de Sistemas y Computación, Universidad Pedagógica y Tecnológica de Colombia, Tunja, Colombia. Magister y Doctor en Ingeniería, Universidad de los Andes, Bogotá, Colombia. PhD en Sciences, Vrije Universiteit Brussel, Bélgica. Profesor asistente, Universidad de los Andes. E-mail: 0-gonzal@uniandes.edu.co

${ }^{4}$ Ingeniero de Sistemas y Computación. Magister y estudiante de Doctorado en Ingeniería, Universidad de los Andes, Bogotá, Colombia. Profesor investigador, Programa de Ingeniería de Sistemas, Universidad Piloto de Colombia, Bogotá, Colombia. E-mail: gilberto-pedraza@unipiloto.edu.co

${ }^{5}$ Ingeniero de Sistemas y Computación. Magister y Doctor en Ingeniería, Universidad de los Andes, Bogotá, Colombia. Profesor asociado, Universidad de los Andes. E-mail: dcorreal@uniandes.edu.co

${ }^{6}$ Ingeniero de Sistemas y Computación. Magister en Tecnologías de Información para el Negocio, Universidad de los Andes, Bogotá, Colombia. E-mail: ga.beltran66@uniandes.edu.co
} 


\section{Abstract}

In the dynamics of collaborative project management, participating organizations make great efforts and provide technical, technological, and human resources to achieve a product they can hardly develop individually. Although there are tools to integrate, monitor, and manage processes for such projects, it is not uncommon to find technological support to manage the knowledge generated during their execution. Usually, this knowledge is part of the experience of participants but it is not recovered or documented nor is it used at an organizational level, thus losing an important asset. In this study we propose a technique in which a Knowledge Management (KM) approach is applied to the management of Collaborative Projects (CP) and where knowledge is expressed in terms of decisions. This is achieved through the analysis of interactions that occur among participants in these projects, the identification and recovery of decisions using Grounded Theory Method (GTM) techniques, and the specification of a set of concrete usage scenarios. The technique was applied in MONO, a framework for integration, control, and optimization of production processes in which digital content companies in the creative industry work collaboratively. The study provides an annotation model that, without being intrusive, allows for the recovery and structuring of knowledge expressed as decisions, thus making possible its replication in other domains.

\section{Keywords}

knowledge management; collaborative project knowledge management; knowledge recovery; knowledge sharing; digital content projects; decision making

\section{Resumen}

En la dinámica de la gestión de proyectos colaborativos, las organizaciones participantes hacen grandes esfuerzos y aportan recursos técnicos, tecnológicos y humanos para conseguir un producto que difícilmente podrán desarrollar de forma individual. Aunque existen las herramientas para ello, no es común encontrar soporte tecnológico para gestionar el conocimiento generado durante su ejecución. Por lo general, este conocimiento hace parte de la experiencia de los participantes, pero ni se recupera, ni se documenta, ni se aprovecha en las organizaciones y se pierde así un importante activo. En este artículo se propone una técnica en la que se aplica un enfoque de administración de conocimiento a la gestión de proyectos colaborativos y donde el conocimiento se expresa en términos de decisiones. Esto se logra por medio del análisis de las interacciones verbales que se dan entre los participantes en este tipo de proyectos, la identificación y recuperación de decisiones mediante técnicas de Grounded Theory Method (GTM) y la especificación de un conjunto de escenarios concretos de uso. La técnica fue aplicada en MONO, un framework para integración, control y optimización de procesos de producción de contenidos digitales en la que trabajan colaborativamente empresas de la industria creativa. El estudio provee un modelo de anotaciones que, sin ser intrusivo, permite recuperar y estructurar conocimiento expresado como decisiones, lo cual hace viable su reproducción en otros dominios.

\section{Palabras clave}

administración de conocimiento; administración de conocimiento en proyectos colaborativos; recuperación de conocimiento; distribución de conocimiento; proyectos de contenido digital; toma de decisiones 


\section{Introduction}

Nowadays, organizations create value based on knowledge [1]-[3] which is considered as processed information by individuals [2] that facilitates decision-making processes [4]. This way, organizations seek to turn the knowledge of its members into a valuable organizational resource [3], and benefit from it, thus generating competitive advantages [5], [6]. An organization that continuously increases its knowledge will be better prepared to deal with the uncertainty of the organizational environment, and is also more competitive. Particularly, organizations that work through projects have greater challenges [5]. In general, projects are initiatives with defined human resources working as a team for a fixed period of time. However, at the end of each project, the team is divided and reallocated; generating the fragmentation of the acquired knowledge which, therefore, cannot be exploited in future projects.

The complexity of this process increases when CP have been developed [5]. In this project type, various companies with different specialties come together to carry out a project that, due to its magnitude, would turn into an impossible task if performed individually [7]. In this case, knowledge is not only fragmented among different individuals within an organization, but also among individuals of different organizations. Therefore, sharing this knowledge is fundamental for organizational learning [1]. The challenge of developing CP between different companies is to ensure effective processes of exchange and integration of knowledge in order to mitigate the risk of reinventing the wheel or repeating past mistakes [8].

In order to provide organizational competitive advantage, Knowledge Management (KM) provides a systematic process for information capture [9], converting it into knowledge which is distributed, used, and evaluated within the organization [10], $[11]$. Specifically, KM is a continuous process of acquiring, retrieval, sharing, and using of knowledge to improve a decision making process [6]. Usually this knowledge is tacit and is part of the experience of each organization member. Currently, many emerging theories and KM models are 
grounded in the notion of tacit knowledge [9]; however, there are few proposals on how tacit knowledge should be operationalized [12], [13].

The literature on this topic describes various techniques for Knowledge Acquiring (KA) and KR. Some of these techniques extract and recover knowledge from physical and electronic documents, databases, follow-up protocols, written or verbal communications [14], and emails, among others. KA is also done by recording of data and/or activities during the development of organizational processes, capturing audio and video [14]. When people are the source of knowledge, the interviews, surveys, and causal cognitive maps have been used [3], [11].

In the Knowledge Sharing (KS) a lot of methods have been proposed [2], [6], [15]-[17]. First, some methods are related to narrative techniques, such as anecdote circles and storytelling. Second, other methods have a theoretical base, for example behavioral models and knowledge maps. Third, several techniques allow generating ideas as in the case of brainstorming, brain writing, and brown bag lunches. Fourth, other techniques are oriented towards building repositories for KM, such as flipchart wikis and semantic wikis. Fifth, there are methods focused on the distribution of experiences and general knowledge, an example of which are forums, workshops, and seminars. Finally, there are methods for learning about the future, such as planning scenarios [18].

Furthermore, Oluikpe [19] has observed the knowledge processes in project teams finding that project teams value explicit knowledge more than tacit knowledge, advising to project teams focus on the implementation and evaluating phases of the project, and proposes KS using methods such as after-action reviews or lessons learned systems [19]. Also, a few studies focus on decisions as knowledge; for example, McKenzie et al. [20] present a framework to guide the organizational discussions about how KM can contribute to a better decision-making capability [20]. This study has an exploratory approach and offers best practices for managers but does not present specific tools to achieve this purpose.

Finally, Wong et al. [21] describe a framework for performance measure of $\mathrm{KM}$ that involves measures about knowledge resources, $\mathrm{KM}$ process and $\mathrm{KM}$ factors, and assumes several metric approaches: financial, non-financial, quantitative, qualitative metrics [21]. In general, there is a variety of literature about frameworks and processes for KM, but very little of it comes to a granular level of detail, depth, and coverage in the creation and use of knowledge [19]. 
This paper presents a technique for $\mathrm{KM}$ in $\mathrm{CP}$ related to creative industries, particularly, in organizations dedicated to the development of digital content. This technique focuses on seizing the situations that arise during the project (e.g. creative differences, change of team members) and the considerations for decision-making (e.g. cost, required time). According to what Ragab and Arisha propose [11], our technique corresponds to the category of KM system and has been developed with a KA approach that focuses on the capture and storage of knowledge in electronic repositories, making it available for decision retrieval, and applying a method of usage scenarios for KS.

The proposal covers the KM life cycle as shown in Figure 1, and includes several techniques: annotation model for KA, annotation to decision mapping for Knowledge Recovery (KR) and generation, and usage scenarios (KS). This proposal is validated on the tool for integration, control, and optimization of processes related to MONO digital content development [22], as well as on KM through a semantic wiki. In a previous study, we present a technique for decision recovery from the annotations [23].

The main contributions of this study are the application of a KR model that allows mapping annotations to decisions, the identification of a set of scenarios to share this knowledge, and the establishment of a number of metrics to validate the impact of the knowledge that is recovered and shared.

This paper is organized as follows: Section 1 presents the theoretical framework of the proposal. Section 2 describes the proposed solution strategy. Section 3 shows how the proposed solution is implemented. Section 5 describes the assessment applied to the proposed solution. Section 5 presents the analysis of the obtained results. Section 6 shows the discussion, Section 7 describes the related work, and the last section presents the conclusion and future work.

\section{Background}

$\mathrm{KM}$ is a continuous process of acquiring and deploying knowledge to improve decision making [4]. This knowledge should reflect the activities that are performed in detail [24], while considering the time constraints of each project [5]. Additionally, tacit knowledge of those involved (acquired knowledge through experience) might become explicit knowledge (documented knowledge), as only explicit knowledge can be transferred as organizational knowledge [5], [25].

Our proposal is focused on CP in the creative industry (particularly organizations dedicated to the development of digital content). These projects are extensive in the creation and transfer of knowledge [7], [26]. 
Figure 1. Knowledge management phases in MONO

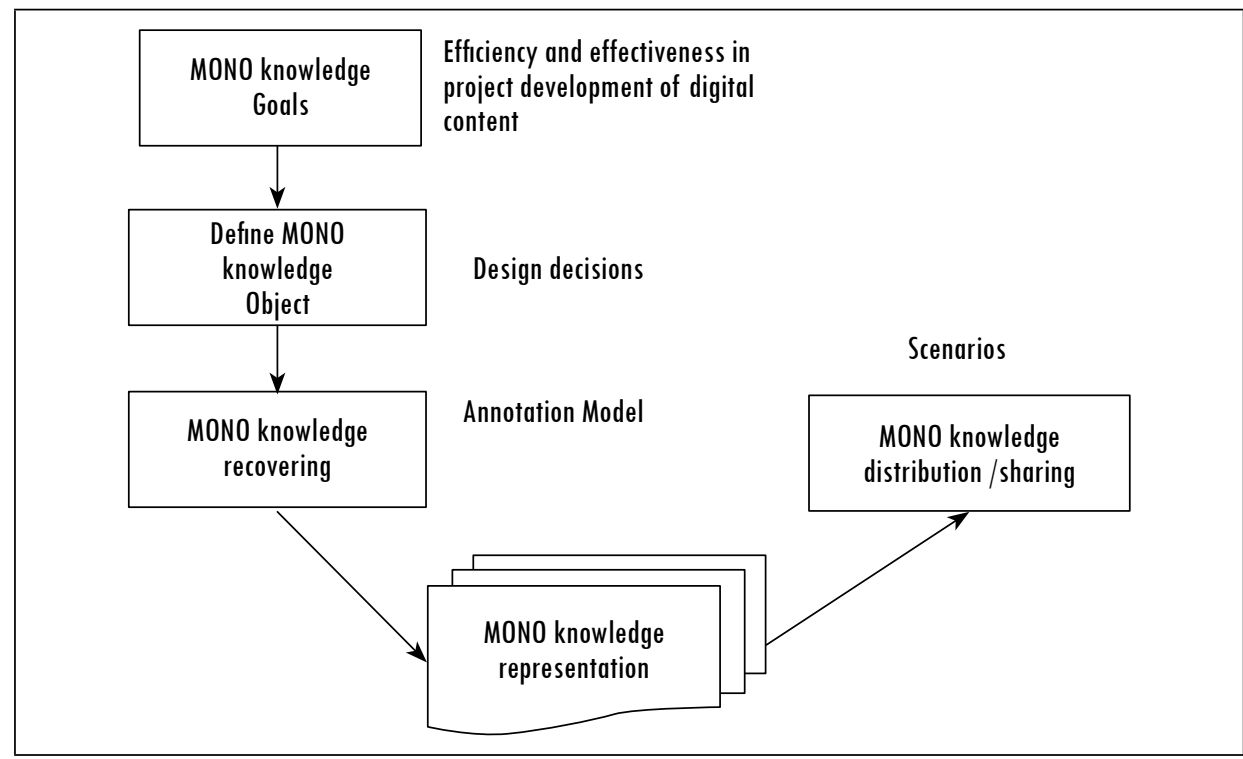

Source: authors' own elaboration

\subsection{Collaborative Projects (CP)}

$\mathrm{CP}$ seek to generate synergies by bringing together different organizations with different specialties around a common project [7]. However, the more people involved and the more interactions between them, the greater the complexity to coordinate the project [27]. Among the most important issues addressed in the development of $\mathrm{CP}$ are the following: lack of communication between project participants, low product quality, poor reusability, a large part of the knowledge domain is handled implicitly in these projects [28].

The requirements of $\mathrm{KM}$ in $\mathrm{CP}$ are focused on those involved in the project and on the interaction between them [7]. Xinghang et al. [29] define four elements that might be considered in KM of CP: The organization of the project (e.g. those involved, the tasks assigned to each one of them), the frameworks, project implementation (e.g. problems encountered and potential solutions), and the decision-making process (along with its consequences).

\subsection{Creative Industry and Digital Content}

Creative industry refers to organizations that combine creation, production and marketing of creative contents [30]. This industry is related to the usage of individual creativity, skills, and talents to achieve innovative products of 
intangible and cultural nature [30]. Also, this industry generates value from the exploitation of intellectual property, the origin of which is creativity and individual skill [31], [32]. Its biggest challenge is having high dependency on stakeholders, because it cannot accurately determine if a product will be commercially successful or not [33].

Moreover, government policy documents suggest that the creative industry is the basis of competitiveness because it provides added value, it is a source for new jobs, and an export potential. Particularly in Colombia, government initiatives include specialized technical assistance, events to publicize the digital content industry, promoting the development of digital content, strengthening specialized capabilities of the digital content industry, strengthening business skills, and international promotion of the digital content industry [34].

The process of creating digital contents is cyclic and incremental, and consists of three sub-processes: pre-production, where the project is conceptualized (e.g. developing the idea, selecting the visual elements) and sketches thereof are made; production, where the predefined content is developed; and post-production, where the final editing of the content is made [22], [35] and product quality interests are met.

\subsection{MONO: Support for $C P$}

MONO is part of the proposals and guidelines that both the Ministry of Foreign Trade and the CONPES 3659 document have been developing in the following lines of action: Industrial organization and business processes, internationalization of the Colombian industry, and infrastructure of knowledge of the digital creation industry [22].

Thus, MONO emerged as a tool for managing CP on digital content creation. Multiple companies can work collaboratively through this tool. MONO is an open source software tool designed to integrate, control, and optimize processes of digital content development. This enables the association of resources (e.g. time, cost, people) to an activity, and these, in turn, to a specific process within the project [22].

\subsection{Knowledge Management (KM)}

In this study, we consider knowledge as processed information by people for decision making in the collaborative project development that includes ideas, facts, and judgements [2]. This knowledge should be obtained from the interpretation, reasoning, or use that people make with the information 
available [21], [36]. So, knowledge is a flow of framed experiences, facts, values, and contextual information that offers a framework for analysis, interpretation, understanding, and evaluation of new situations [17] to take right decisions [36].

Particularly, KM is considered as a set of practices used by participants in $\mathrm{CP}$ to identify, create, represent, distribute, and enable the decision making activities [16]. These include knowledge incorporated by individuals or through processes or organizational project activities. The approach emphasizes the collection and management of information from one or more sources and the distribution of this information to one or more hearings, in order to facilitate and streamline decision making. Also, $\mathrm{KM}$ is related to the design and implementation of tools, process, systems, and structures to improve the creation, sharing, and use of knowledge [37].

\subsection{Scenarios}

Scenarios are an analysis tool for identifying possible future situations and how to respond to these [38]. In general, scenarios describe a possible future situation and/or the story of how a state could come to happen [39]. In particular, a scenario represents a complex situation involving a model that shows real problematic situations and provides mechanisms to solve them [40] through context and environmental elements that interact to meet specific knowledge needs.

Several studies in KS apply the scenario planning method for learning on future situations identifying the factors and drives that cause greater impact. These uncertain factors and drivers are extrapolated to elaborate diverging stories in order to increase the project team knowledge [18].

\subsection{KS Measurement}

The measurement of knowledge is a complex and challenging task because of the intangible nature [41], subjectivity, and embeddedness of knowledge [42]. In the academic community there is no consensus regarding the criteria for measuring knowledge. At first, some authors had associated measuring knowledge with organizational knowledge stock at some time, called intellectual capital [3]. However, the spectrum of criteria is very wide, ranging from process, resources, and factors to the outcome and from interpersonal behavior to patent citations [42]. The general trend is to build taxonomies with multiple perspectives such as: knowledge creation [42] and KM perfor- 
mance [21]. Also, these taxonomies adopt qualitative approaches that include questionnaires, expert interviews, case studies, and surveys, as well as a quantitative approach to measure explicit knowledge using historical data to avoid the drawbacks of subjective judgment of empirical results [21]. Some specific metrics are categorized as human capital, knowledge and information capital, intellectual property, acquisition and retrieval, internalization, creation and generation, application and utilization, codification and storing, transferring and sharing, among others [21].

\subsection{Grounded Theory Method (GTM)}

Method proposed by Glaser and Strauss [43]-[45] to provisionally discover, develop, and verify a theory based on a phenomenon through systematic data collection and analysis thereof [46]. The method is based on the discovery of conceptual properties and categories from the comparative analysis of qualitative data.

The procedure proposed by GTM consists of (1) the familiarization of data to formulate a set of base ideas and questions around them; (2) the coding and categorization of a small number of concepts to categorize the studied phenomenon. This categorization is performed by identifying concepts with their properties and dimensions (open coding), rebuilding data by establishing hierarchies of concepts (axial coding), and integrating and refining concepts in a theory to explain the phenomenon under investigation (selective coding); and (3) the formulation of hypotheses concerning the theory [47].

\section{Proposed Strategy}

The proposed solution is based on the Design Verbal Intervention Analysis (DVIA) [14], a technique used to understand how software architects design architectures in design meetings. In this study, the interactions among the participants in the collaborative project management are represented as annotations developed by participants while performing the activities described in the defined processes for each project. In general, the result of these activities is a set of artifacts. An artifact is any intermediate tangible or intangible result around which the discussion revolves while performing one or more activities of a project. The set of annotations associated with an artifact is called a discussion thread. The proposed solution is based on the three steps described below (See Figure 2): 
Figure 2. Proposed strategy to manage knowledge in collaborative project development

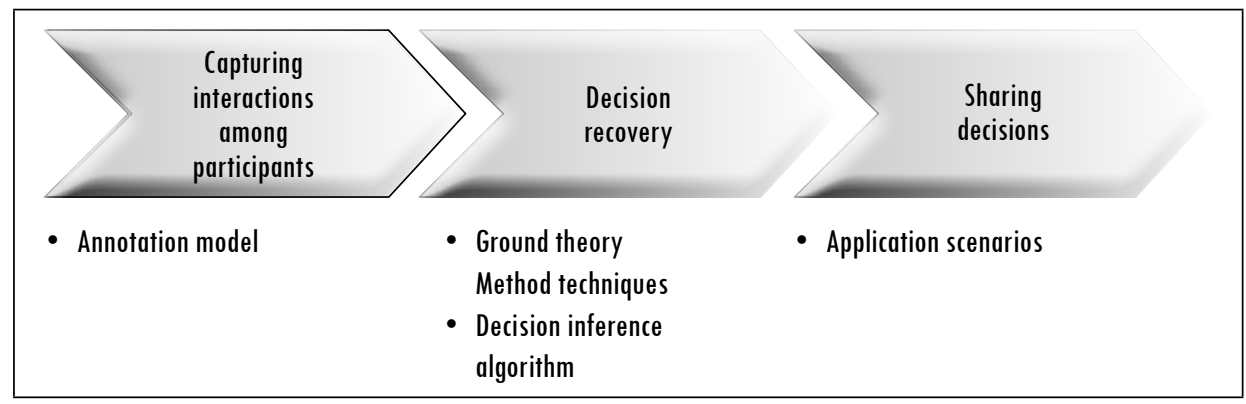

Source: authors' own elaboration

\subsection{Capturing Interactions among Participants}

In this activity, interactions, communications, or comments (annotations) that occur among participants during the process of making digital content, are captured. These discussions occur around various tasks or are aimed at the construction of certain intermediate artifacts that are used to support or are part of the final product that is expected. An annotation model was defined for structuring of these interactions, as described below.

The annotation model allows sorting and organizing the interactions or messages that the participants exchanged during the development of a collaborative project. This model applies principles related to problem identification, restructuring, and troubleshooting. Figure 3 shows the annotation model for MONO and Table 1 describes each of these annotations.

Figure 3 shows the relationships between annotations: an issue finds possible solutions in an orientation. In order to understand the orientation provided by others, participants can make requests for clarification; these requests are answered with explanations. The guidelines are also assessed through comparisons that lead to agreements or disagreements among the participants. This way, comparisons lead to the choice of an orientation. On the other hand, there are guidelines that satisfy concerns, are compulsory, and are not discussed; so they are mandatory orientations. 
Table 1. Knowledge application scenarios

\begin{tabular}{|l|l|}
\hline \multicolumn{1}{|c|}{ Annotation } & \multicolumn{1}{c|}{ Description } \\
\hline Issue & $\begin{array}{l}\text { Represents a motivation, need, interest, or matter regarding an artifact that } \\
\text { must be resolved. }\end{array}$ \\
\hline $\begin{array}{l}\text { Request for } \\
\text { clarification }\end{array}$ & $\begin{array}{l}\text { It is a clarification, observation, or correction about aspects described in the } \\
\text { construction of digital content, which are of interest to or the responsibility of } \\
\text { a participant. }\end{array}$ \\
\hline Explanation & This is the answer or explanation to a request for clarification. \\
\hline Orientation & $\begin{array}{l}\text { It is a contribution with approaches, indications, or suggestions about how to } \\
\text { resolve a concern, problem, or need that motivated the discussion. }\end{array}$ \\
\hline $\begin{array}{l}\text { Mandatory } \\
\text { Orientation }\end{array}$ & $\begin{array}{l}\text { This is a guideline or opinion to resolve a previously expressed concern. They } \\
\text { are compulsory and cannot be argued. }\end{array}$ \\
\hline Assessment & $\begin{array}{l}\text { It is a judgment about the impact of one or several orientations expressed } \\
\text { above. }\end{array}$ \\
\hline Agreement & $\begin{array}{l}\text { Represents a consensus or acceptance of an orientation that satisfies a concern } \\
\text { being discussed. }\end{array}$ \\
\hline Disagreement & $\begin{array}{l}\text { Expresses a rejection position towards guidelines or orientations intended to } \\
\text { solve an issue. }\end{array}$ \\
\hline Choice & Represents an approach that has already been accepted. \\
\hline
\end{tabular}

Source: [14].

Figure 3. Annotation model for MONO

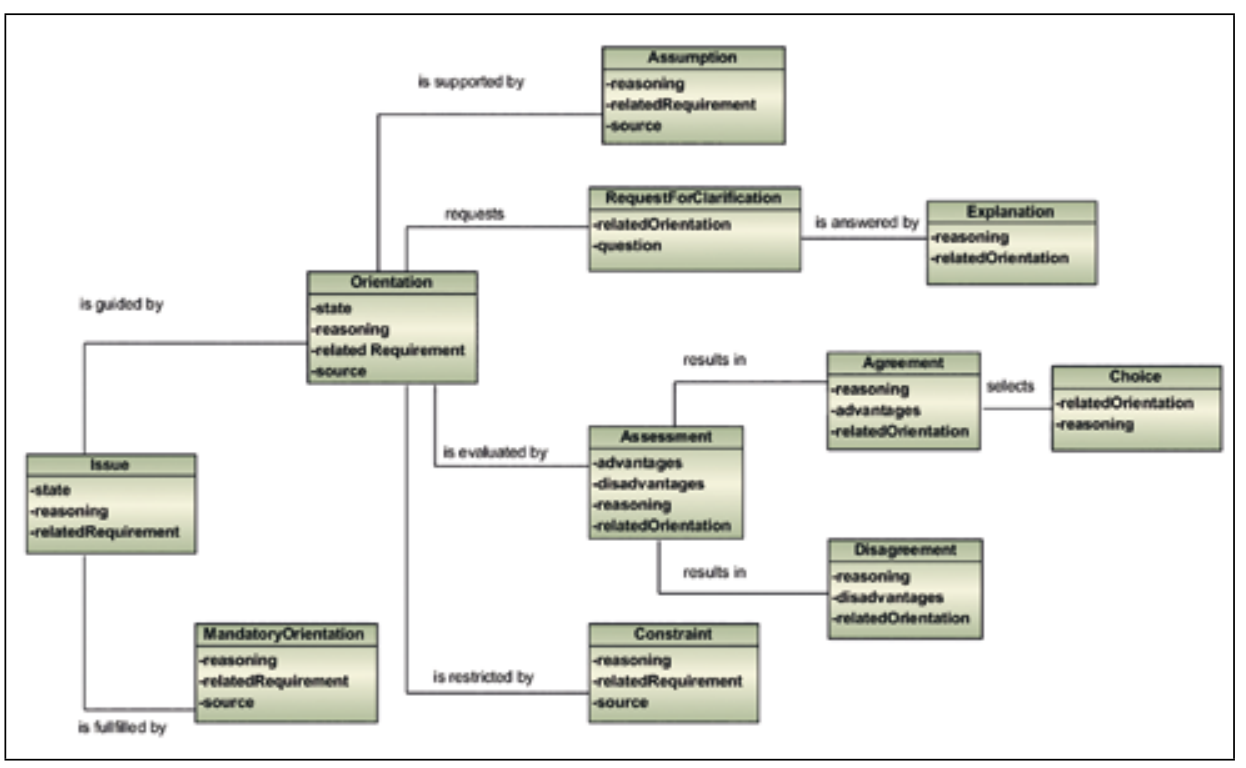

Source: author's own elaboration 


\subsection{Decision Recovery}

During the management of $\mathrm{CP}$, participants in each activity make decisions regarding tasks being carried out or intermediate artifacts in manufacturing. Usually, these decisions are not documented along with the artifacts; they are implicit and remain in the minds of those responsible for them. The solution to this situation is to recover these decisions from the interactions (annotations) among participants. Therefore, this study adopts the proposal presented in [48], where a decision is motivated by a concern, interest, or problem to be solved. When looking for the solution, those responsible must analyze, evaluate, and prioritize between the available possible solutions, and select the one that offers the best solution advantages.

\subsubsection{Decision Inference Algorithm}

The goal of the algorithm is to abstract a set of high-level decision issues, and assign the annotations collected during the previous stage to each decision item. The algorithm described below is based on the GTM [43]:

A. Identification of relevant concepts (Open coding):

- Through an analysis of the frequency of occurrence of individual terms in the texts that comprise annotations, candidate terms to be elevated to concepts are identified.

- Through a process of constant comparison [44] terms are associated with contexts, and the next level of abstraction is established: Concepts.

- Definition of concept-context associations. Below are interrelated concepts to generate concept-context associations. This process of constant comparison can raise prioritized terms to a concept level. These associations are analyzed semantically to leave only those that best explain a set of annotations. These concept-context associations are categories in a third level of abstraction.

B. Defining association hierarchies (Axial coding). Concept-context associations are classified by the type of process they belong to, which enables establishing hierarchies between associations by level of abstraction.

C) Refinement of the core issues decision [45] (Selective coding). Each decision theme selected as leaf in the hierarchy is assigned the corresponding annotations. To achieve this, the following correspondences are made, as shown Figure 4:

(1) Assign every Issue annotation to a decision motivator.

(2) Assign every Orientation, Request for Clarification, and Explanation annotation to a decision solution alternative. 
(3) Assign every Assessment, Agreement, and Disagreement annotation to a decision alternative evaluation.

(4) Assign every Mandatory Orientation and Choice annotation to a decision choice.

Figure 4. Assigning annotations to decision components

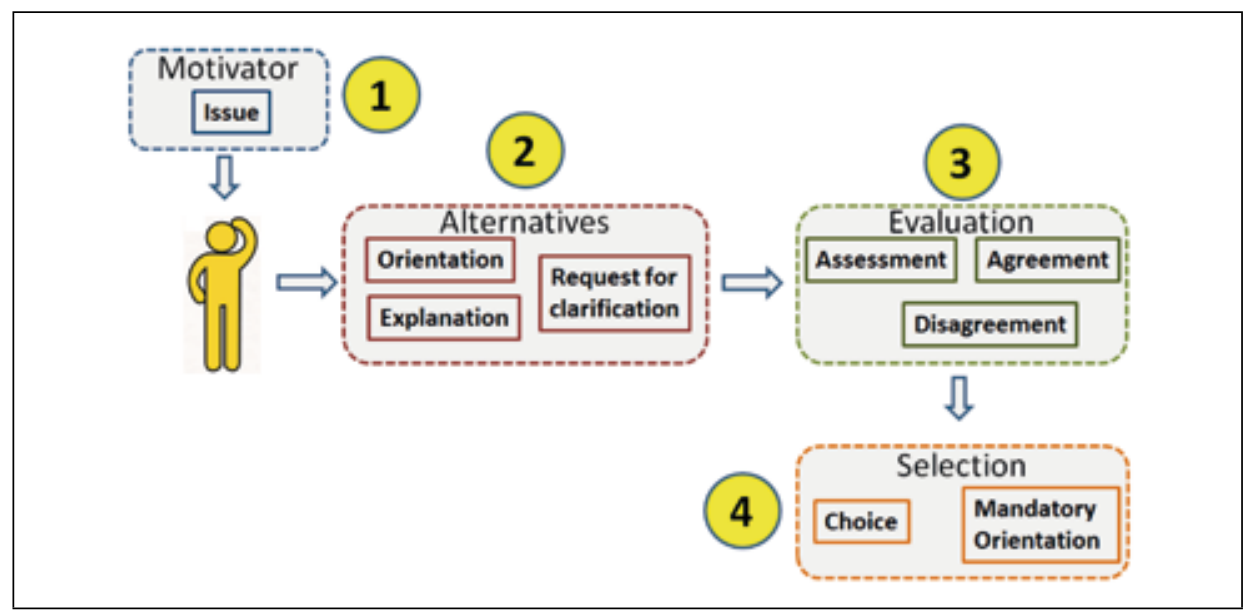

Source: authors' own elaboration

\subsection{Knowledge Usage Scenarios}

Figure 5 shows the proposed structure used to represent application scenarios. In $\mathrm{CP}$, a large number of participants must know and understand the decisions made during the project in order to achieve advantages while developing activities under their responsibility during project development.

A scenario is a template [46] where several elements are defined, as shown in Table 2.

Most metrics on measuring knowledge focus on the organization itself because knowledge is a critical factor and is considered as the source of value in the future for organizations [49]. In this study, response measurement is aimed at measuring the achievement of the objectives proposed at each stage. No direct but rather indirect metrics are used, specifically oriented towards measuring the amount of rework that can be avoided with the reasoning regarding recovered decisions. In order to share and reuse the knowledge gained in the form of decisions, we identified and defined the following possible application scenarios, as shown in Table 3. 
Figure 5. Structure of a decision-based knowledge application scenario

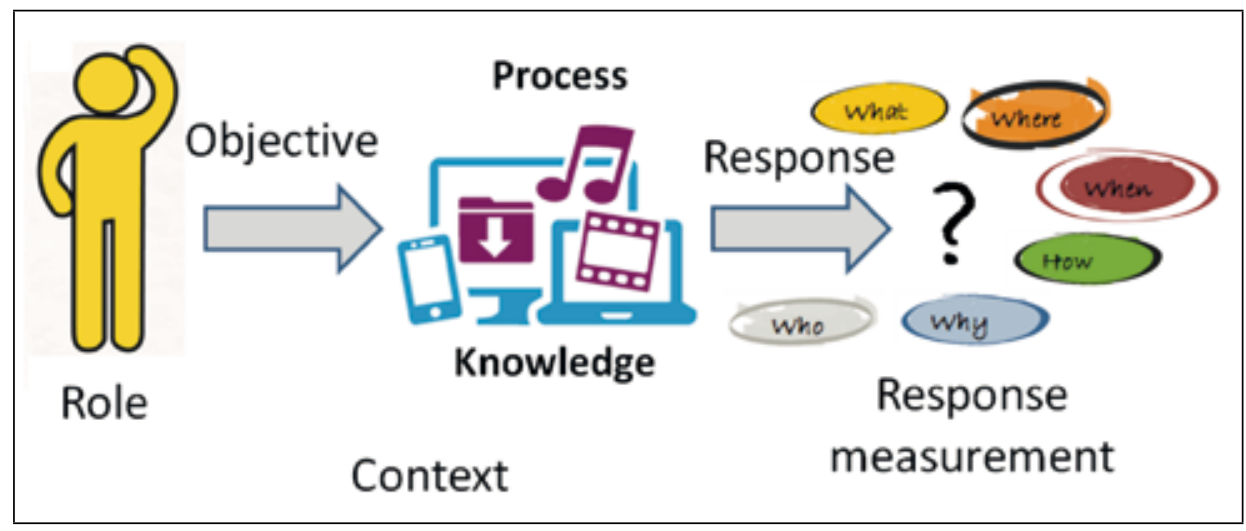

Source: authors' own elaboration

Table 2. Elements of a knowledge application scenario

\begin{tabular}{|l|l|}
\hline Scenario element & \multicolumn{1}{c|}{ Description } \\
\hline Role & Establishes who must take advantage of knowledge. \\
\hline Objective & $\begin{array}{l}\text { Defines the purpose or need for knowledge of the participant, namely, what } \\
\text { or its usage type. }\end{array}$ \\
\hline Context & Describes the process or project phase where the scenario is carried out. \\
\hline Response & Defines the kind of results expected by the scenario. \\
\hline $\begin{array}{l}\text { Response } \\
\text { measurement }\end{array}$ & $\begin{array}{l}\text { Describes how to measure whether or not the knowledge scenario is } \\
\text { achieved. }\end{array}$ \\
\hline
\end{tabular}

Source: authors' own elaboration

Table 3. Knowledge application scenarios

\begin{tabular}{|c|l|l|l|l|l|}
\hline$\#$ & \multicolumn{1}{|c|}{ Role } & \multicolumn{1}{|c|}{ Objective } & \multicolumn{1}{c|}{ Context } & \multicolumn{1}{c|}{ Response } & \multicolumn{1}{c|}{$\begin{array}{c}\text { Response } \\
\text { Measurement }\end{array}$} \\
\hline & & $\begin{array}{l}\text { Resolve conflict } \\
\text { between tasks } \\
\text { assigned to } \\
\text { an employee } \\
\text { compared } \\
\text { with the work } \\
\text { performed by } \\
\text { other workers }\end{array}$ & $\begin{array}{l}\text { Phase or project } \\
\text { process: } \\
\text { Preproduction, } \\
\text { production and, } \\
\text { postproduction } \\
\text { Environment } \\
\text { Development of } \\
\text { (Animator) } \\
\text { dechnical } \\
\text { leader }\end{array}$ & $\begin{array}{l}\text { Decisions } \\
\text { associated } \\
\text { with } \\
\text { conflicting } \\
\text { tasks }\end{array}$ & $\begin{array}{l}\text { Number of } \\
\text { decisions / } \\
\text { Number of } \\
\text { assigned tasks in } \\
\text { conflict }\end{array}$ \\
\hline
\end{tabular}




\begin{tabular}{|c|c|c|c|c|c|}
\hline$\#$ & Role & Objective & Context & Response & $\begin{array}{c}\text { Response } \\
\text { Measurement }\end{array}$ \\
\hline 2 & $\begin{array}{l}\text { Technical } \\
\text { leader, } \\
\text { Project } \\
\text { Manager, } \\
\text { Quality } \\
\text { Manager }\end{array}$ & $\begin{array}{l}\text { Identification of } \\
\text { reusable artifacts } \\
\text { within the same } \\
\text { project or in other } \\
\text { projects }\end{array}$ & $\begin{array}{l}\text { Phase or project } \\
\text { process: } \\
\text { Preproduction, } \\
\text { production and, } \\
\text { postproduction } \\
\text { Environment } \\
\text { Development of } \\
\text { digital content. }\end{array}$ & $\begin{array}{l}\text { Set of } \\
\text { decisions and } \\
\text { justifications } \\
\text { associated } \\
\text { with a digital } \\
\text { content. }\end{array}$ & $\begin{array}{l}\text { Number of } \\
\text { decisions / Total } \\
\text { number of } \\
\text { attributes }\end{array}$ \\
\hline 3 & $\begin{array}{l}\text { Worker } \\
\text { (Animator), } \\
\text { Technical } \\
\text { Leader, } \\
\text { Product } \\
\text { owner }\end{array}$ & $\begin{array}{l}\text { Avoid rework } \\
\text { to identify or } \\
\text { understand } \\
\text { customer } \\
\text { preferences for the } \\
\text { product }\end{array}$ & $\begin{array}{l}\text { Phase or project } \\
\text { process: } \\
\text { Preproduction, } \\
\text { production and, } \\
\text { postproduction } \\
\text { Environment } \\
\text { Several workers. } \\
\text { Existence } \\
\text { of relations } \\
\text { between the } \\
\text { tasks performed } \\
\text { by different } \\
\text { workers }\end{array}$ & $\begin{array}{l}\text { Decisions } \\
\text { associated } \\
\text { with } \\
\text { conflicting } \\
\text { tasks }\end{array}$ & $\begin{array}{l}\text { Characteristics } \\
\text { defined by } \\
\text { the customer } \\
\text { / Number } \\
\text { of decisions } \\
\text { associated } \\
\text { with customer } \\
\text { preferences }\end{array}$ \\
\hline 4 & $\begin{array}{l}\text { Worker } \\
\text { (Animator) }\end{array}$ & $\begin{array}{l}\text { Understanding } \\
\text { of prior Project } \\
\text { progress }\end{array}$ & $\begin{array}{l}\text { Phase or project } \\
\text { process: } \\
\text { Preproduction, } \\
\text { production and, } \\
\text { postproduction } \\
\text { Environment } \\
\text { Arrivals or } \\
\text { changes in team } \\
\text { members. }\end{array}$ & $\begin{array}{l}\text { The set of } \\
\text { decisions } \\
\text { associated } \\
\text { with a } \\
\text { project in } \\
\text { chronological } \\
\text { order }\end{array}$ & $\begin{array}{l}\text { Number of } \\
\text { decisions / Total } \\
\text { number of } \\
\text { assigned tasks }\end{array}$ \\
\hline 5 & $\begin{array}{l}\text { Worker } \\
\text { (Animator) } \\
\text { Technical } \\
\text { leader, } \\
\text { Quality } \\
\text { Manager, } \\
\text { Project } \\
\text { Manager, } \\
\text { Product } \\
\text { owner }\end{array}$ & $\begin{array}{l}\text { Determine the } \\
\text { impact of changes } \\
\text { to characteristics } \\
\text { previously } \\
\text { established for } \\
\text { digital content }\end{array}$ & $\begin{array}{l}\text { Phase or project } \\
\text { process: } \\
\text { Preproduction, } \\
\text { production and, } \\
\text { postproduction } \\
\text { Environment } \\
\text { Changes in the } \\
\text { characteristics } \\
\text { of a digital } \\
\text { content that } \\
\text { was previously } \\
\text { developed } \\
\text { or is under } \\
\text { construction }\end{array}$ & $\begin{array}{l}\text { Set of } \\
\text { decisions and } \\
\text { justifications } \\
\text { associated } \\
\text { with a digital } \\
\text { content. }\end{array}$ & $\begin{array}{l}\text { Number of } \\
\text { decisions } \\
\text { associated with } \\
\text { digital content } \\
\text { / Number of } \\
\text { content features }\end{array}$ \\
\hline
\end{tabular}

Source: authors' own elaboration 


\subsubsection{Scenario: Conflict among Assigned Tasks}

This scenario corresponds to situations in which various actors involved in the development of a single artifact, with responsibilities that are dependent from each other because of artifact processing tasks, overlap or are highly coupled. The conflict arises because there is a lack of knowledge regarding previous decisions in which certain features of the product are defined, or concerning the tools and techniques to help it function. Table 3 describes the elements that are relevant to this situation, which aims to identify and resolve conflicts between the tasks performed by a worker and the results to be expected.

\subsubsection{Scenario: Artifact Reuse}

Artifact reuse is common in CP. However, the greatest difficulty of reuse is that usually the artifact itself does not describe the problem it solves, nor the benefits, preconditions, and dependencies for its implementation; thus, making it very difficult to adapt to a new context. Table 3 describes the characteristics of this scenario in row \# 2, which results in efficiency and effectiveness in the project.

\subsubsection{Scenario: Knowing Customer Preferences}

This scenario applies to projects where customer preference overrides standard procedures and applicable best practices whilst developing a product. Table 3 describes the characteristics of the scenario in row \#3 and has the advantage of saving time and effort. By knowing customer preferences in advance -regarding similar artifacts within the same project or in a different one-could save time and effort.

\subsubsection{Scenario: Change of Project Participants}

This scenario represents situations related to a change in the participants assigned to a collaborative project. The main problem is that these changes require a complex learning process from the new members, which often leads to delays in implementation. Table 3 describes the characteristics of the scenario in row \#4. Among other advantages, this scenario saves time and effort in the learning process of new participants. The scenario allows the new member of the team to analyze and understand the decisions that were previously made in the development of an artifact and justify the current state of the artifact. 


\subsubsection{Scenario: Change in the Characteristics of an Artifact}

This is related to the introduction of new features or requirements for change in the product or intermediate artifacts already developed; therefore it is necessary to determine the feasibility and impact of the new features. Table 3 describes the characteristics of the scenario in row \#5. Among other advantages, this scenario enables the reduction of the effort to analyze the impact of the new changes in one or more specified artifacts. For example, a change request to an animated element of a digital content can impact all other animated elements, which leads to the final decision of developing the content again.

\section{Implementation}

The strategy was implemented using MediaWiki [50] along with the Semantic Media Wiki (SMW) [51] extension. MediaWiki is a free software developed in PHP and used to create websites where pages can be edited using a web browser directly for creating, viewing, or modifying content that is usually shared. SMW allows annotating web pages with semantic data for subsequent use as knowledge. In this study, properties, templates, and SMW forms were created to capture annotations, recover decisions, and define queries to describe usage scenarios.

Figure 6 shows the annotation template and contains the following attributes: annotation type according to the classification presented in section 2.1, date, role or actor, artifact, state (under discussion or closed), source or origin, comment and subject, criteria or keyword.

Figure 6. Annotation template in a Semantic Media Wiki

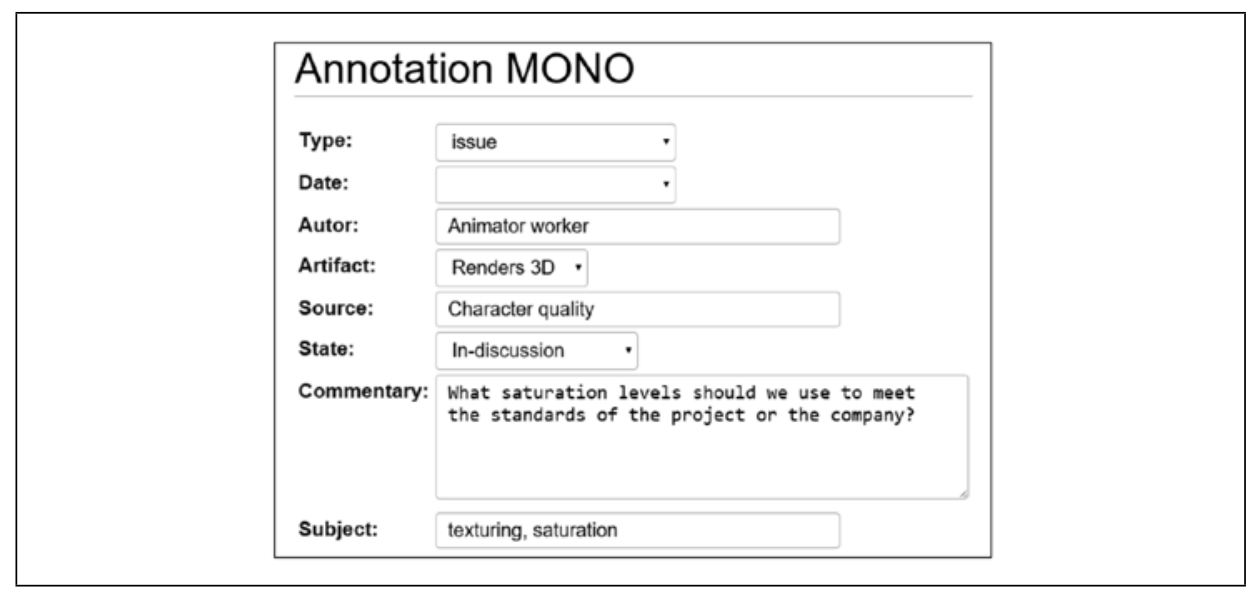

Source: authors' own elaboration 
Information related to artifacts is collected using the template depicted in Figure 7. Among other attributes, it contains the name of the artifact, the MONO activity that develops it, a description, the customer, and the state of the artifact (In-development, In-Review, Approved, Unapproved).

Figure 7. Artifact template in a Semantic Media Wiki

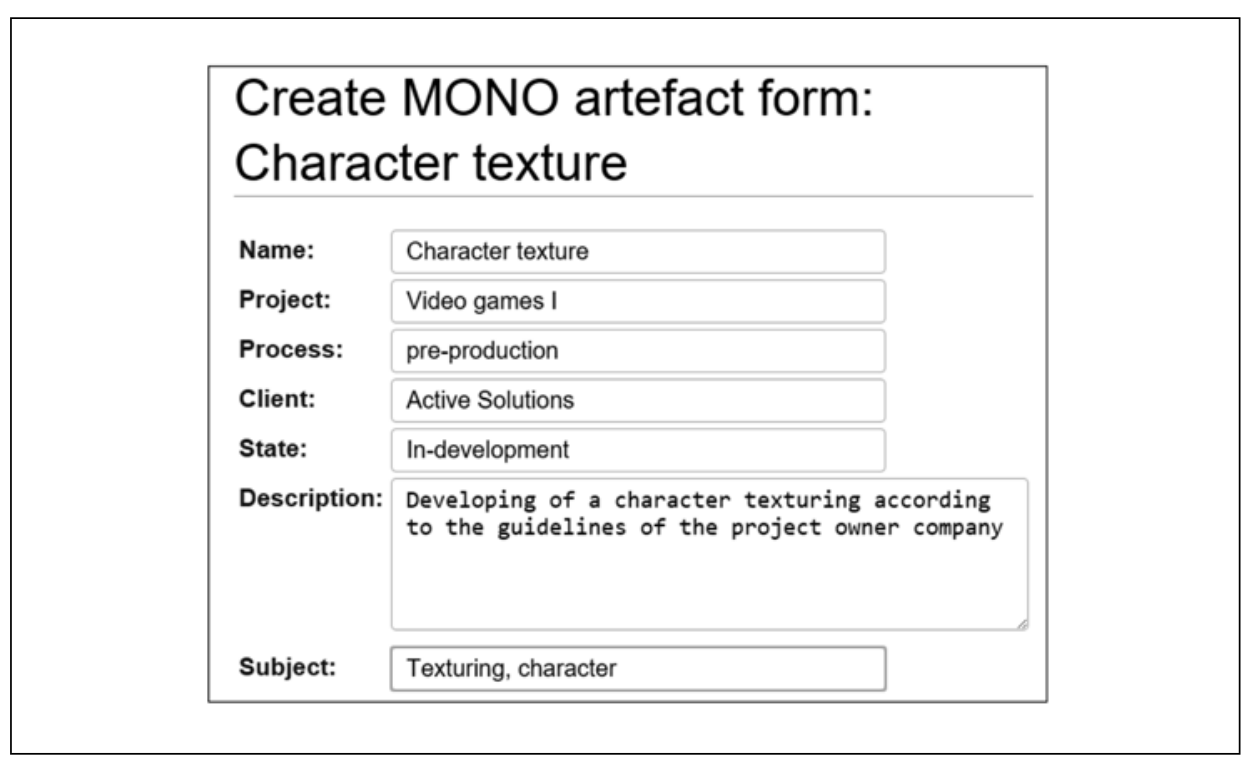

Source: authors' own elaboration

To respond to usage scenarios, we used the parser "ask" function to build "Inline queries" of Semantic Media Wiki [51]. This function performs a semantic search on the information gathered in the wiki.

\section{Validation}

Validation aims at exploring decision recovery and their usefulness to carry out the responsibilities of project participants and for future decisions. This is accomplished based on the comments and annotations expressed by participants during the management of $\mathrm{CP}$, without requiring an additional effort on the part of the participants.

\subsection{Case study: MONO}

For this study, we considered three MONO processes (see section 1.3) related to the digital content creation described in Section 1.2: 
- Preproduction-Animation is a structured template to animate videogames. Figure 8 defines the set of activities that take part in this process. These activities are delimited by the start and end events. Task represents the work to be performed, for example Model and unwrap characters, props, or sets. Gateways (diamonds) represent branching points, for example characters, animation, approved or not approved.

- Production-Animation is a template structured for videogame animation (See Figure 8).

- Posproduction-Animation is a visual effects and 3D integration layout template (See Figure 8).

\subsection{Participants and Study Execution}

To validate this study, we carried out a project that involved three companies from the gaming industry, which performed the three processes described in section 4.1. Each company contributed one professional with technological training, experience of one year in MONO projects, and knowledge of the 3 processes described in the case study. These professionals were given the responsibility to fulfill the following roles: Quality Manager, Project Manager, preproduction Project Manager, postproduction Project Manager, Technical Leader, Product Owner, Worker (animator).

The study was carried out following the steps described below:

Preparation. Participants were trained in the use of the MONO semantic wiki - KM as a complementary tool to MONO in order to facilitate communication among project participants. Furthermore, they were explained the definition and use of annotations, and shown examples of each.

Execution. The three defined processes were developed along five weeks and discussion threads were recorded for 31 artifacts.

Postexecution. The definition of artifacts and their corresponding threads were processed to recover the implicit decisions of each one (see section 2.3), and the usage scenarios were applied described in section 2.4. The project was successfully completed. 


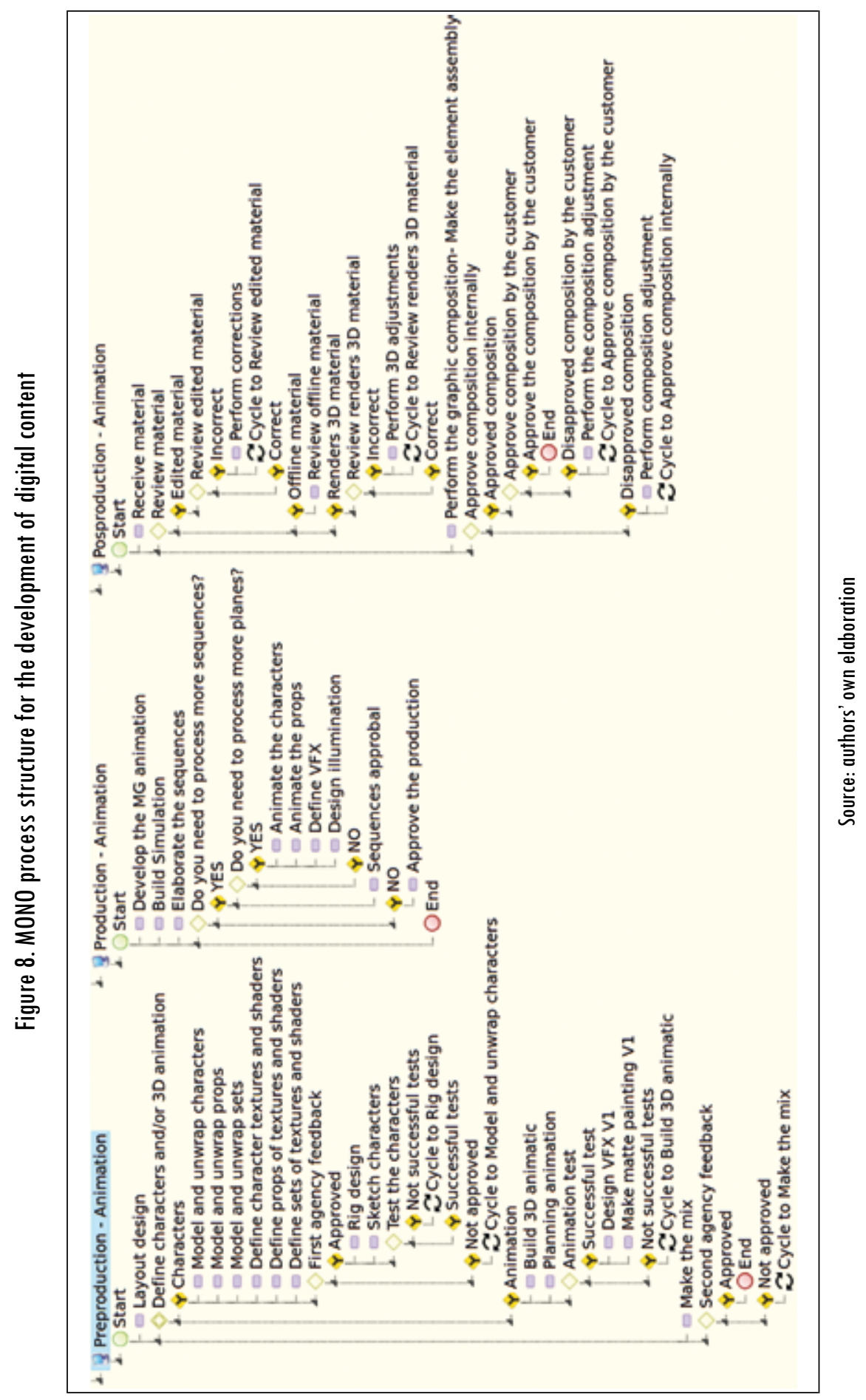

Ing. Univ. Bogotá (Colombia), 20 (2): 267-302, julio-diciembre de 2016 


\section{Results}

Results are presented according to the order established in the proposed solution (section 2). Figure 9 shows the distribution by type of annotation of 134 captured annotations, according to the model described in section 2.2.

Figure 9. Distribution of annotations by type

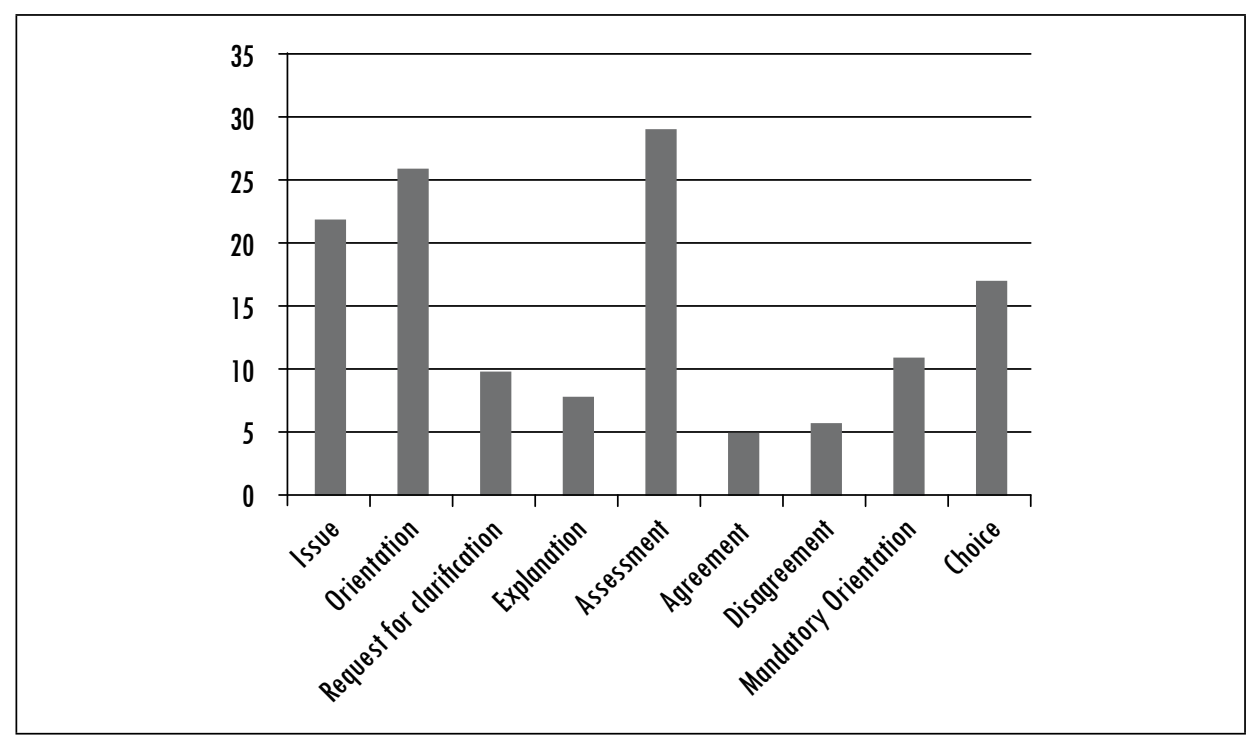

Source: authors' own elaboration

Also, the percentage distributions of seven participant roles are shown in Figure 10.

\subsection{Identification of Decisions}

In order to determine decision topics, the 134 entries described by participants in the Wiki are used as the data source for this part of the study.

\subsubsection{Identification of Relevant Concepts (Open Coding)}

Figure 11 shows the frequency distribution of the terms identified in the annotations. The terms most frequently identified, such as character, customer, animation, among others, were compared comprehensively to select key and context-related concepts. 
Figure 10. Distribution of annotations participant's role

$\square$ Animation worker
$\square$ Technical leader
$\square$ Project manager
$\begin{aligned} & \text { Pre-production project } \\ & \text { manager } \\ & \text { Post-production project } \\ & \text { manager } \\ & \square \text { Production owner }\end{aligned}$
$15 \%$

Source: authors' own elaboration

\subsubsection{Hierarchy Definition (Axial Coding)}

Partnerships were created based on main concepts and context concepts. To simplify the analysis, we considered as valid associations only those that are actually in texts or can be deducted from them. Figure 12 shows some relevant associations.

Figure 11. Frequency distribution of occurrence of identified terms

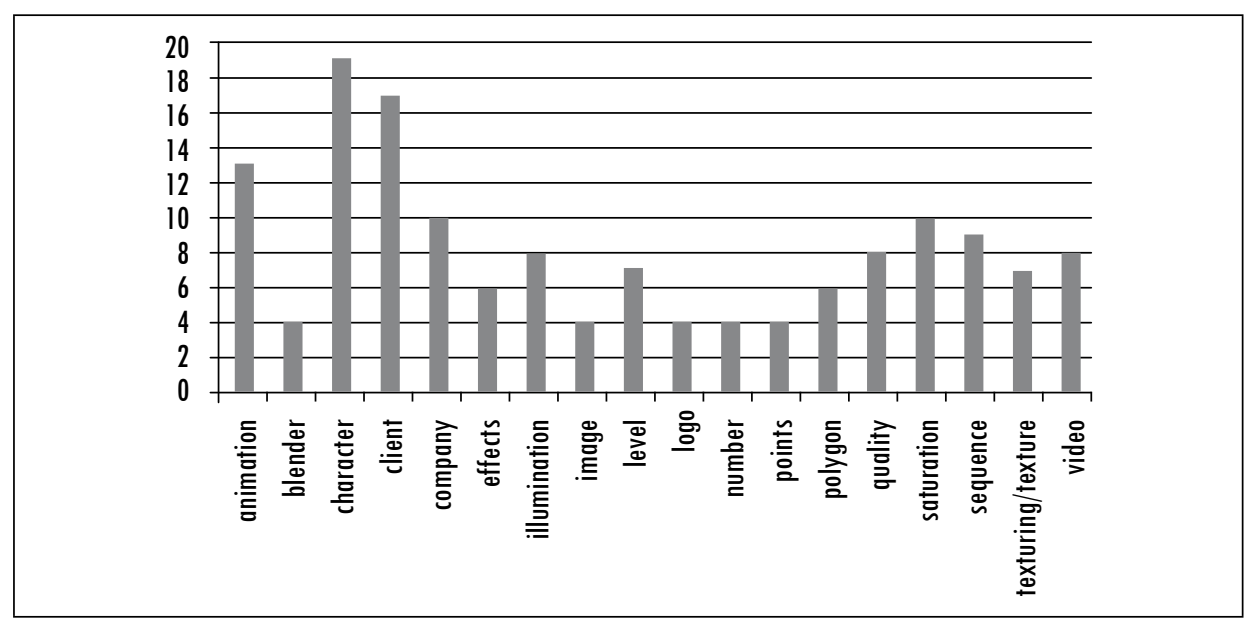

Source: authors' own elaboration 
Figure 12. Identification of decision topics

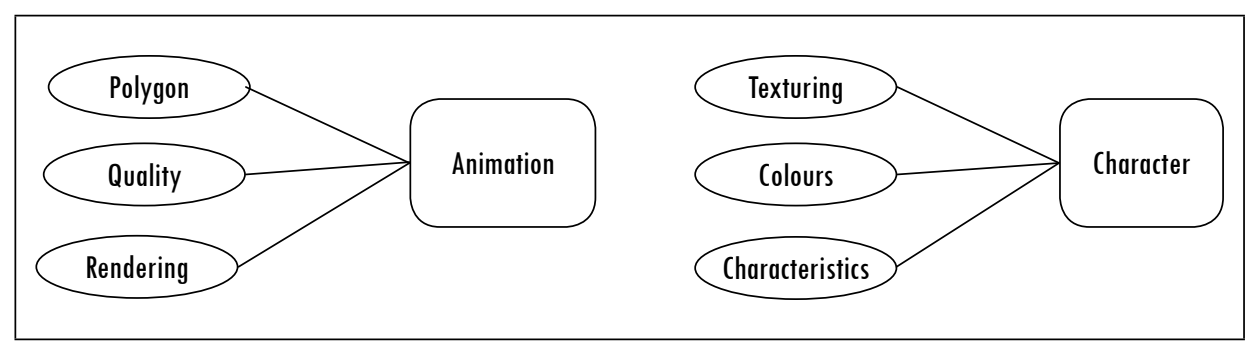

Source: authors' own elaboration

\subsubsection{Refinement (Selective Coding)}

Based on the prioritized relationships and using the phase field of the process, we defined the decision topics hierarchy, as shown in Figure 13. Figure 13 shows the hierarchy of categories and concepts through several cycles of refinement. Lastly, 18 decisions that correspond to the leaves of the trees shown in Figure 11 were selected. Considering that a decision can mention several issues or topics, we found the following proportions: $39 \%$ of the decisions mentioned the subject "Character," 28\% refer to "Video," $39 \%$ have the subject "Animation."

Figure 13. Decision topics hierarchy

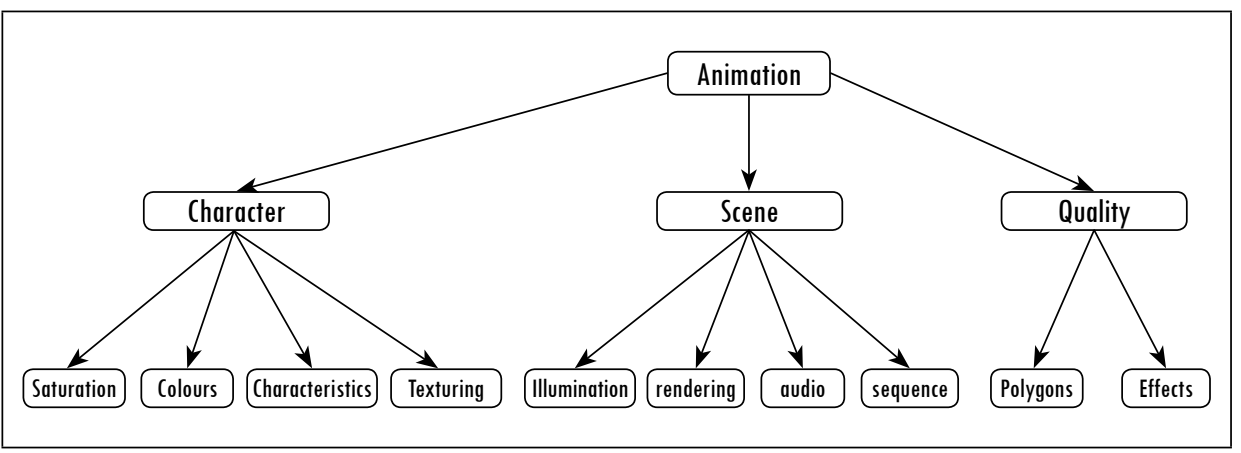

Source: authors' own elaboration

Figure 14 shows the structure of a recovered decision for the Character Animation activity. This semantic structure shows the decision elements: motivator, alternatives, evaluation, and selection, and the relations among these which are built from the annotation grouping. 


\subsection{Validation of Usage Scenarios}

The "changes in the characteristics of an artifact" scenario, described in section2.3.5, requires knowing the decisions associated with a specific artifact in order to explain its current characteristics. In this case, the scenario is presented for a "Request of change to the final video". The answer involves making known the decisions associated with the "Final Video" artifact. Table 4 shows the decisions corresponding to the "Video" topic. A total of 4 decisions were recovered. This way, the recovery of information related to cost, time management, and efficiency becomes evident. This information becomes valuable knowledge expressed as best practices that can be applied in future updates of the artifact or future activities.

The "knowing customer preferences" scenarios are described in section2.3.3 and enable the establishment of the preferences associated with a customer, thus making it easier for whoever is responsible for the content to establish a general set of characteristics. Table 5 shows the two decisions that were recovered, which are associated with the customer and refer to characteristics regarding the quality of the material that was received.

Figure 14. Recovered decision for the Character Animation activity

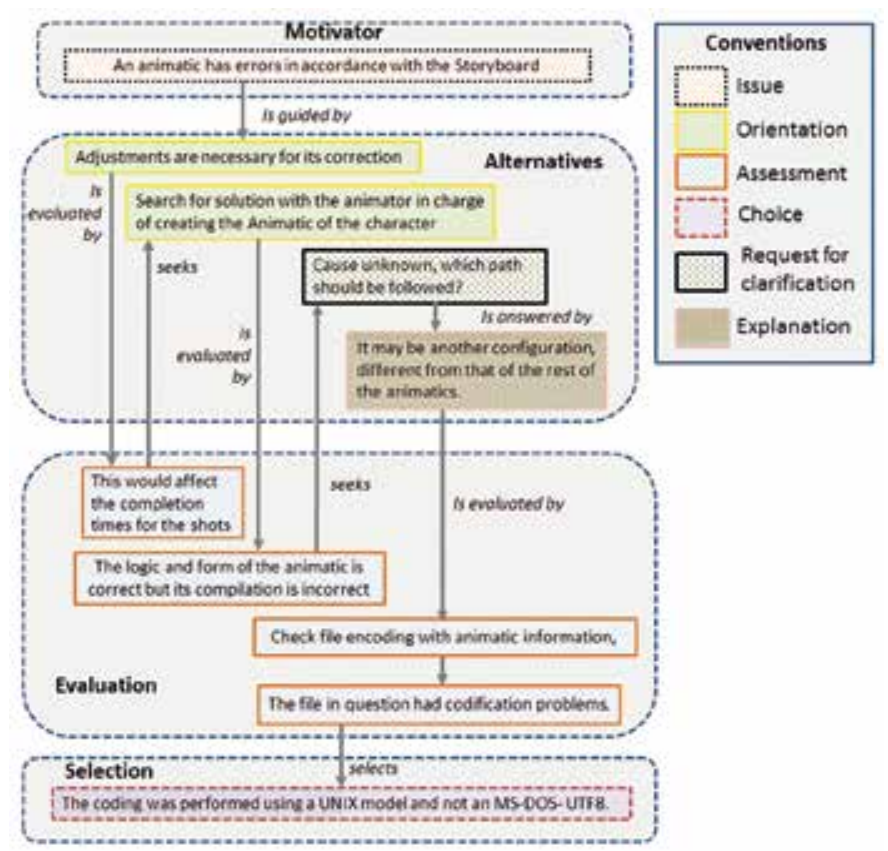

Source: authors' own elaboration 
Table 4. Result of the scenario with a change in the characteristics of an artifact

\begin{tabular}{|c|c|c|c|c|c|}
\hline Artifact & Motivator & Alternatives & Evaluation & Selection & $\begin{array}{l}\text { Knowledge } \\
\text { contribution }\end{array}$ \\
\hline $\begin{array}{l}\text { Final } \\
\text { video }\end{array}$ & $\begin{array}{l}\text { Reduction } \\
\text { of the effects } \\
\text { applied in the } \\
\text { remaining } \\
\text { shots }\end{array}$ & $\begin{array}{l}\text { Problems with } \\
\text { the transitions } \\
\text { between } \\
\text { animated takes } \\
\text { and effects }\end{array}$ & $\begin{array}{l}\text { If possible } \\
\text { to be } \\
\text { applied }\end{array}$ & $\begin{array}{l}\text { Apply to the last } \\
\text { part of the video, } \\
\text { making sure that } \\
\text { the product is } \\
\text { acceptable for the } \\
\text { client }\end{array}$ & $\begin{array}{l}\text { Time delays } \\
\text { of the project } \\
\text { cannot be } \\
\text { compensated } \\
\text { with a } \\
\text { reduction of the } \\
\text { effects on the } \\
\text { remaining shots } \\
\text { of the video }\end{array}$ \\
\hline $\begin{array}{l}\text { Final } \\
\text { video }\end{array}$ & $\begin{array}{l}\text { Changes } \\
\text { in the } \\
\text { logo of the } \\
\text { costumer's } \\
\text { company }\end{array}$ & $\begin{array}{l}\text {-The client pays } \\
\text { an additional } \\
\text { value to build a } \\
\text { sequence } \\
\text { - Was the } \\
\text { additional time } \\
\text { taken into } \\
\text { account? } \\
\text { - Two additional } \\
\text { days were given }\end{array}$ & $\begin{array}{l}\text { - It is not } \\
\text { necessary } \\
\text { to change } \\
\text { textures, } \\
\text { props, and } \\
\text { characters }\end{array}$ & $\begin{array}{l}\text { Changes have to } \\
\text { be made only to } \\
\text { the sequences of } \\
\text { the logo }\end{array}$ & $\begin{array}{l}\text { The requests for } \\
\text { change made } \\
\text { by the customer } \\
\text { are not to be } \\
\text { underestimated, } \\
\text { the true impact } \\
\text { on all product } \\
\text { sequences must } \\
\text { be analyzed }\end{array}$ \\
\hline $\begin{array}{l}\text { Final } \\
\text { video }\end{array}$ & $\begin{array}{l}\text { Lighting } \\
\text { spots do not } \\
\text { correspond } \\
\text { to the ones } \\
\text { found on the } \\
\text { scenario }\end{array}$ & $\begin{array}{l}\text { Changes in } \\
\text { a character's } \\
\text { trajectory } \\
\text { due to trials } \\
\text { that were } \\
\text { performed. }\end{array}$ & $\begin{array}{l}\text { Recalculate } \\
\text { the spots }\end{array}$ & $\begin{array}{l}\text { The worker has } \\
\text { to fix those spots } \\
\text { in four (4) hours }\end{array}$ & $\begin{array}{l}\text { Define the } \\
\text { lighting } \\
\text { spots after } \\
\text { establishing the } \\
\text { characters' final } \\
\text { trajectory is } \\
\text { better. }\end{array}$ \\
\hline $\begin{array}{l}\text { Final } \\
\text { video }\end{array}$ & $\begin{array}{l}\text { Simulation of } \\
\text { each object } \\
\text { built by the } \\
\text { animation }\end{array}$ & $\begin{array}{l}\text { - Simulation of } \\
\text { texturing } \\
\text { - Call for a } \\
\text { meeting to } \\
\text { identify the } \\
\text { cause }\end{array}$ & $\begin{array}{l}\text { Mistakes } \\
\text { in objects } \\
\text { that } \\
\text { are not } \\
\text { correctly } \\
\text { visualized }\end{array}$ & $\begin{array}{l}\text { Continue with } \\
\text { the elaboration of } \\
\text { material }\end{array}$ & $\begin{array}{l}\text { The } \\
\text { inconsistencies } \\
\text { found on } \\
\text { product } \\
\text { sequences } \\
\text { should not } \\
\text { delay the } \\
\text { production } \\
\text { of the ones } \\
\text { pending }\end{array}$ \\
\hline
\end{tabular}

Source: authors' own elaboration 
Table 5. Result of the scenario knowing customer preferences

\begin{tabular}{|c|c|c|c|c|}
\hline Motivator & Alternatives & Evaluation & Selection & $\begin{array}{l}\text { Knowledge } \\
\text { contribution }\end{array}$ \\
\hline $\begin{array}{l}\text { 1- After receiving } \\
\text { and revising } \\
\text { the animation } \\
\text { material, problems } \\
\text { with the sequences } \\
\text { were found in the } \\
\text { edited material } \\
\text { 2- The resolution } \\
\text { of offline material } \\
\text { has errors of image } \\
\text { quality. 3- And of } \\
\text { 3D -Animation }\end{array}$ & $\begin{array}{l}\text { 4- The } \\
\text { expressions } \\
\text { of characters } \\
\text { have to be } \\
\text { improved, as } \\
\text { shown in the } \\
\text { animatic }\end{array}$ & $\begin{array}{l}\text { 5- Indeed, there } \\
\text { are problems in the } \\
\text { edited material. } \\
\text { 7- That material } \\
\text { should not be } \\
\text { changed }\end{array}$ & $\begin{array}{l}\text { 6- Upon } \\
\text { request of } \\
\text { the client, } \\
\text { it has to } \\
\text { remain as } \\
\text { it is }\end{array}$ & $\begin{array}{l}\text { Despite the low } \\
\text { quality of the } \\
\text { sequences and the } \\
\text { image. } \\
\text { "By request of } \\
\text { the customer" the } \\
\text { characteristics should } \\
\text { be maintained } \\
\text { because they were } \\
\text { pre-established by the } \\
\text { customer. }\end{array}$ \\
\hline $\begin{array}{l}1 \text { - The } \\
\text { material has an } \\
\text { illumination } \\
\text { problem }\end{array}$ & $\begin{array}{l}4- \\
\text { Nevertheless, } \\
\text { it is } \\
\text { important, } \\
\text { in this case, } \\
\text { to play } \\
\text { with the } \\
\text { combination } \\
\text { of colors and } \\
\text { to supply } \\
\text { the lack of } \\
\text { illumination } \\
6-\text { A change } \\
\text { in the } \\
\text { illumination } \\
\text { is suggested }\end{array}$ & $\begin{array}{l}\text { 2- According to my } \\
\text { experience, a faint } \\
\text { illumination tires } \\
\text { the spectator and } \\
\text { does not go with } \\
\text { what the client } \\
\text { wants to show. } \\
\text { 3- Illumination } \\
\text { for such scenes is } \\
\text { usually not as dark } \\
\text { - However, colors } \\
\text { get saturated when } \\
\text { manipulated. } \\
7 \text { - Even though his } \\
\text { suggestion is not } \\
\text { that ludicrous, }\end{array}$ & $\begin{array}{l}8 \text { - it is not } \\
\text { possible to } \\
\text { change the } \\
\text { illumination } \\
\text { due to a } \\
\text { client's } \\
\text { request }\end{array}$ & $\begin{array}{l}\text { The lack of lighting in } \\
\text { the scene. } \\
\text { If the ones responsible } \\
\text { for creating sequences, } \\
\text { adding image } \\
\text { characteristics and } \\
\text { scene lighting acquire } \\
\text { this knowledge before } \\
\text { they start working on } \\
\text { the project, it might } \\
\text { be possible to avoid } \\
\text { reworking, which } \\
\text { certainly happens } \\
\text { when ignoring this } \\
\text { knowledge. }\end{array}$ \\
\hline
\end{tabular}

Source: authors' own creation

The "Conflict among assigned tasks" scenario, described in section 2.3.1, happens due to the increasing production of digital content. When making the first versions of the artifacts, certain decisions that have an impact on future increments are made during the first cycles. These increments take place on the next cycles and are performed by others who are responsible. Consequently, some conflicts may arise between the tasks assigned to others, thus causing increases in cost, time, and effort spent making the required corrections.Table 6 shows the decisions related to conflicts between assigned tasks during the "PROPS" animation. 


\section{Discussion}

This study has argued for and validated a recovery and sharing technique of knowledge expressed as decisions on CP. The inputs of this technique are the interactions or comments that occur among participants in these projects. The advantage of this approach is that it helps make the recording of these interactions a daily activity that does not imply an additional effort to fulfill the responsibilities assigned to participants [14]. These interactions are analyzed and organized in order to convert them into a structure with a higher level of abstraction such as the implicit decisions described throughout this paper.

Table 6. Results of the scenario conflict among assigned tasks

\begin{tabular}{|c|c|c|c|c|}
\hline Motivator & Alternatives & Evaluation & Selection & $\begin{array}{l}\text { Knowledge } \\
\text { contribution }\end{array}$ \\
\hline $\begin{array}{l}\text { 1- Detailed } \\
\text { and accurate } \\
\text { models are } \\
\text { required, } \\
\text { so there is } \\
\text { the need to } \\
\text { establish the } \\
\text { quantity of } \\
\text { polygons for } \\
\text { the PROPS }\end{array}$ & $\begin{array}{l}\text { 2- If a big amount of } \\
\text { polygons is used. } \\
\text { 4- Which is the most } \\
\text { appropriate number } \\
\text { of polygons without } \\
\text { losing quality? } \\
5 \text { - Our experience } \\
\text { in the company } \\
\text { indicates that the } \\
\text { adequate number of } \\
\text { polygons is } 2478 \text {, }\end{array}$ & $\begin{array}{l}\text { 3- We take the } \\
\text { risk of reducing } \\
\text { performance on } \\
\text { image processing. } \\
\text { 6- We can } \\
\text { balance the loses, } \\
\text { using shaders }\end{array}$ & $\begin{array}{l}\text { 7- We are } \\
\text { going to keep } \\
\text { this amount } \\
\text { and see how it } \\
\text { works }\end{array}$ & $\begin{array}{l}\text { When there } \\
\text { are frequently } \\
\text { decisions related } \\
\text { to the same } \\
\text { concern, these } \\
\text { decisions produce } \\
\text { a set of facts, } \\
\text { assumptions, and } \\
\text { learned lessons } \\
\text { that support } \\
\text { future decisions. }\end{array}$ \\
\hline $\begin{array}{l}1 \text { - As a non- } \\
\text { associated } \\
\text { animator, } \\
\text { my work } \\
\text { is to model } \\
\text { the PROPS } \\
\text { by using } \\
\text { polygons. }\end{array}$ & $\begin{array}{l}\text { 2- From my } \\
\text { experience, the } \\
\text { adequate number of } \\
\text { polygons is } 320004 \\
\text { - The company uses } \\
\text { only } 2478 \text { polygon }\end{array}$ & $\begin{array}{l}\text { 3- Because it } \\
\text { gets closer to the } \\
\text { clients and to a } \\
\text { better experience } \\
\text { due to the quality } \\
\text { that is generated, } \\
\text { the definition that } \\
\text { is achieved and } \\
\text { texturing quality. } \\
5 \text { - Because it } \\
\text { is a standard } \\
\text { average to ensure } \\
\text { performance on } \\
\text { processing and an } \\
\text { acceptable quality } \\
\text { for clients. }\end{array}$ & $\begin{array}{l}\text { 6- Although } \\
\text { the suggestion } \\
\text { was well } \\
\text { received, } \\
\text { the other } \\
\text { animators used } \\
\text { the standard } \\
(2478) \text { and } \\
\text { wanted the } \\
\text { product to } \\
\text { follow this } \\
\text { scheme. }\end{array}$ & $\begin{array}{l}\text { These facts, } \\
\text { assumptions, and } \\
\text { lessons learned } \\
\text { may come into } \\
\text { conflict with } \\
\text { standardized } \\
\text { principles in the } \\
\text { industry. }\end{array}$ \\
\hline
\end{tabular}




\begin{tabular}{|c|c|c|c|c|}
\hline Motivator & Alternatives & Evaluation & Selection & $\begin{array}{l}\text { Knowledge } \\
\text { contribution }\end{array}$ \\
\hline $\begin{array}{l}\text { 1-The } \\
\text { client has } \\
\text { demanded } \\
\text { that the } \\
\text { animation } \\
\text { quality of the } \\
\text { houses used } \\
\text { in the video } \\
\text { that have } \\
\text { animated } \\
\text { doors and } \\
\text { windows, } \\
\text { must be } \\
\text { improved. }\end{array}$ & $\begin{array}{l}\text { 2-A bigger amount } \\
\text { of polygons for } \\
\text { rendering }\end{array}$ & $\begin{array}{l}\text { 3-however, this } \\
\text { would imply } \\
\text { redesigning the } \\
\text { PROPs related to } \\
\text { the houses. } \\
5 \text { - therefore, no } \\
\text { change will be } \\
\text { made, }\end{array}$ & $\begin{array}{l}\text { 4- Given that } \\
\text { the standard } \\
\text { use of } 2478 \\
\text { polygons is } \\
\text { a company } \\
\text { quality policy, } \\
\text { even if the } \\
\text { petition was } \\
\text { accepted when } \\
\text { the contract } \\
\text { was signed, } \\
\text { this rule } \\
\text { should always } \\
\text { be followed. } \\
6 \text { - Given } \\
\text { that it is a } \\
\text { preventive } \\
\text { measure to } \\
\text { take care of } \\
\text { the company's } \\
\text { image. }\end{array}$ & $\begin{array}{l}\text { Decision makers } \\
\text { need to take into } \\
\text { account the most } \\
\text { important criteria } \\
\text { for prioritizing } \\
\text { possible } \\
\text { alternatives } \\
\text { (conflicting } \\
\text { decisions) and } \\
\text { they should be } \\
\text { supported by the } \\
\text { contributions } \\
\text { of previous } \\
\text { decisions. } \\
\text { In this case the } \\
\text { criteria are: } \\
\text { Performance, } \\
\text { graphic Customer } \\
\text { Experience } \\
\text { Rendering cost. }\end{array}$ \\
\hline
\end{tabular}

Source: authors' own elaboration

The scope of the proposed technique extends beyond a diagnosis of a current situation and a set of best practices presented in previous studies [52], [53] because the validation of our technique shows concrete data about the operationalization of tacit KR from the interactions among participants in digital content projects.

In contrast to previous studies such as Ambrosini and Bowman [12], our study provides usage scenarios for specific KS and reuse in the context of collaborative project development. The analysis of these results supports the technical viability and allows establishing some important findings.

\subsection{Annotations as a Source of Decision Recovery}

Based on 134 annotations, these results have allowed recovering 18 decisions with an average rate of four annotations for every decision. Additionally, we could establish that the characterization of the decisions depends on achieving a clear separation between the problem-solution spaces. We found annotations with different implicit elements. For example, the combination of needs that correspond to decision motivators that involve orientations or alternative solutions, also implicit elements between evaluation of alternatives, agreements, and 
selection of the solution. Therefore it was necessary to break some annotations to recover their implicit meanings.

\subsection{Recovered Decisions Characterization}

The study provides a positive indication regarding CP for the development of digital content. Although the results are applicable to the domain of the digital content creation, the GTM instruments as identification of relevant concepts, hierarchy definition, and refinement require a redefinition for application in other contexts [54].

Using GTM contributed to the formalization of an a priori intuitive technique for identifying and categorizing decision issues. However, the effort required to implement this technique is very high because it can only be performed by analysts with experience in the field and good skills to identify and relate concepts. Furthermore, there are few tools to make this task easier.

\subsection{Knowledge Application Scenarios}

A successful outcome of the study was to make recovery decisions evident. Nevertheless, this alone does not guarantee benefits for participants in CP. Therefore, management scenarios helped making sense of a wide range of knowledge described as decisions. Although this knowledge seems structured, it is very specific and vaguely related so as to benefit those interested in the project, because it has implicit and explicit meanings.

The scenarios allow establishing axes to identify common issues associated with specific needs of project stakeholders such as: settling conflicts among tasks, determining the impact of change, knowing customer preferences, among others.

\subsection{Study Limitations}

Our study has limitations in relation to the validation. Although validation collects data and demonstrates the feasibility of our proposed technique, validation does not demonstrate the effectiveness of this with empirical data. We hope to make a more formal experimental validation and statistics in the next stage of the project.

Although the feasibility of the technique is demonstrated, the cost of implementation is high because it requires people dedicated exclusively to the process of mapping from annotations to decisions. Coming soon, we will expect the addition of a software system that allows partial automation of this process. 


\section{Related Work}

Ambrosini and Bowman [12] propose a technique to operationalize the tacit $\mathrm{KR}$ in form of skills by means of cognitive maps, causal maps, self-Q technique, semi-structured interviews, and metaphors for the identification of success-oriented factors and factors that promote success. At the end, they present a set of general guidelines focused on the process but they do not describe specific tools for this mapping [55]-[58]. Our study shows specific tools for mapping among interventions and decisions based on GTM.

Rittel and Kunz [55] propose Issue Based Information Systems (IBIS), a method to capture the reasoning behind the design decisions on software projects supported in the interactions between those responsible for them. IBIS proposes multiple elements to capture this reasoning (e.g. questions, concerns, arguments, possible answers). Also, Pedraza-Garcia et al. [14] propose DVIA, a set of phases to analyze design meetings, extract verbal contributions, and retrieve design decisions made by software architects. The annotation model presented in this project was derived from contextualizing these works to the domain of digital content creation.

Xinghang et al. [29] propose a method of identification and classification of knowledge to learn from the experience of a design project through a project memoir. This memoir describes project organization, the frameworks used as reference, project implementation (including problems and potential solutions) and the decision-making process. It, then, identifies the relationships between these elements to analyze a decision based on the arguments, proposals, and problems that appear when making it. This approach is similar to our proposal, but we include a semantic wiki, which can capture and use information insofar as the project progresses, and does not classify knowledge after completion.

Xiong et al. [56] present a project for online collaborative development to produce 3D animations. KM focuses on aligning knowledge (common understanding of the project). However, it does not include considerations regarding decision-making process.

Pipek et al. [57] identify features additional to KM. It focuses on the information at hand about the experience of human resources and on how factors specific to people affect this information (e.g. presenting something as acquired skills when in reality those skills are not well developed, in order to stand out). These considerations are analyzed by our proposal, since there is a large human component in the processes that were analyzed. 
Terzieva [58], Abke et al. [59] and Yang et al. [60] identify KS mechanisms. According to [58], most commonly used mechanisms to preserve and transfer knowledge are the shared folders (explicit) and post project reviews or postmortem (tacit). Additionally, Abke et al. [59] and Yang et al. [60] define a Wiki as a KS mechanism, focused on academic processes. Abke et al. [60] use the wiki so that students can simultaneously generate, store, and transfer knowledge, while Yang et al. [60] uses the wiki to collect knowledge from a work team based on the individual contributions of each team member. These mechanisms are useful but can make it difficult to use the information when it increases. For this reason, we decided to incorporate a semantic wiki.

Wong et al. [21] describe a framework for performance measure of KM based on ideas from various authors that involves measures about knowledge resources, $\mathrm{KM}$ process and $\mathrm{KM}$ factors, and defines a set of metrics related to financial, non-financial, quantitative, and qualitative indicators [21]. In contrast, we adopt an approach from the perspective of the knowledge beneficiary where the amount of information provided in terms of number and quality of decisions is measured.

McKenzie et al. [20] present a framework to guide organizational discussions about how KM) can contribute to better decision-making capability based on the exploration of decision making process with experienced practitioners [20]. The result is a maturity model for evaluating of the applied organizational knowledge on decision making activities and offers a set of best practices for managers. In contrast, our study allows a more granular and contextualized analysis of the decisions taken to meet the concerns expressed by the project team during the digital content building.

\section{Conclusion and Future Work}

This article presents an initial investigation into the application of a systematic and qualitative recovery and distribution technique for knowledge structured as decisions, on collaborative project management. The technique relies on capturing interactions (annotations) that occur during daily discussions among the participants in these projects. For the identification and mapping of the annotations to the topics of decision we used GTM techniques. The technique was validated with MONO, a tool for integration, control, and optimization of digital content development processes.

The main contributions of the technique are applying an annotation model for $\mathrm{KA}$, analyzing the feasibility of decisions as knowledge in $\mathrm{CP}$, showing ev- 
idences of the recovery of decisions based on the annotation model, and the specification of a set of scenarios for KS among the participants in CP. These contributions are extensible to other domains besides digital content production.

Among other advantages, the technique does not generate additional work for project participants when using daily arguments between them as an input. It also allowed to give meaning and structure to a wide range of knowledge in terms of a set of specific needs expressed as usage scenarios.

Among other results, the study establishes that the characterization of the decisions depends on achieving a clear separation between the problem-solution spaces at an annotation level. Some of the limitations we encountered were the need for skilled personnel within the domain and with skills to identify, analyze, and relate concepts. This results in a relatively large effort to implement, so it should be contrasted with the profit that is to be obtained. Also, as a result of using GTM, the generalization of results is limited to other domains.

As future work, we propose the refinement of the proposed annotation model in order to eliminate the gaps that appear from the interpretation of the various collaborative project management situations. We also propose to balance the effort and cost of this technique with respect to the benefit to be obtained. This benefit can be expressed in terms of rework time and resources that result from not having this knowledge. Although some elements of the technique have been tested in the field of software architectures [14], we intend apply it in other domains such as software projects with agile methodologies.

\section{References}

[1] M. Almeida and A. Soares, "Knowledge sharing in project-based organizations: Overcoming the informational limbo," Int.J. Inform. Manage., vol. 34, no. 6, pp. 770-779, 2014.

[2] S. Wang and R.A. Noe, "Knowledge sharing: A review and directions for future research," Hum. Resour. Manage. R., vol. 20, no. 2, pp. 115-31, 2010.

[3] M.A.F. Ragab and A. Arisha. "Knowledge management and measurement: A critical review,” J. Knowl. Manage., vol. 17, no. 6, pp. 873-901, 2013.

[4] F. Burstein and S. Carlsson, "Decision support through knowledge management," in Handbook on Decision Support Systems 1, ser. International Handbooks Information System. Berlin: Springer, 2008, pp. 103-120.

[5] F. Lindner and A. Wald, "Success factors of knowledge management in temporary organizations," Int. J. Project Manage., vol. 29, no. 7, pp. 877-888, 2011.

[6] H. Abdul-Jalal, P. Toulson, and D. Tweed, "Knowledge sharing success for sustaining organizational competitive advantage," Procedia Econ. Financ., vol. 7, pp. 150-157, 2013. 
[7] D. Paul, "Collaborative activities in virtual settings: case studies of telemedicine," in Proc. of the 38th Annu.Hawaii Int. Conf. on System Sciences, pp. 147a, 2005.

[8] S. Pemsel and A. Wiewiora, "Project management office a knowledge broker in projectbased organisations," Int. J. Project Manage., vol. 31, no. 1, pp. 31-42, 2013.

[9] I. Nonaka, "A dynamic theory of organizational knowledge creation," Org. Sci., vol. 5, no. 1, pp. 14-37, 1994.

[10] R. Nicolas, "Knowledge management impacts on decision making process," J. Knowl. Manage., vol. 8, no. 1 pp. 20-31, 2004.

[11] G.D. Bhatt, "Organizing knowledge in the knowledge development cycle," J. Knowl. Manage, vol. 4, no. 1, pp. 15-26, 2000.

[12] V. Ambrosini and C. Bowman, "Tacit knowledge: some suggestions for operationalization," J. Manage. Stud., vol. 38 no. 6, pp. 811-29, 2001.

[13] J. Castillo, "A note on the concept of tacit knowledge," J. Manage. Inq., vol. 11, no. 1, pp. 46-57, 2002.

[14] G. Pedraza-García, H. Astudillo, and D. Correal, "DVIA: Understanding how software architects make decisions in design meetings," in Proc. of the 2015 Eur. Conf. on Software Architecture Workshops, ser. ECSAW '15. New York, NY, USA: ACM, pp. 51:1-51:7, 2015.

[15] T. Nesheim and J. Smith, "Knowledge sharing in projects: does employment arrangement matter?," Pers. Rev., vol. 44, no. 2, pp. 255-269, 2015.

[16] R.H. Stevens, J. Millage, and S, Clark. "Waves of knowledge management: The flow between explicit and tacit knowledge," Am.J. Econ. Bus. Adm., vol. 2, no. 1, pp. 129-135, 2010.

[17] T.H. Davenport and L. Prusak, "Working knowledge: How organizations manage what they know," Ubiquity, vol. 2000, no. 1, 2000.

[18] P.J.H. Schoemaker, "Scenario Planning: A tool for strategic thinking," Sloan Manage. Rev., vol. 36, no. 2, pp. 25, 1995.

[19] P.I. Oluikpe, "Knowledge creation and utilization in project teams," J. Knowl. Manage., vol. 19, no. 2, pp. 351-371, 2015.

[20] J. McKenzie, C. Winkelen, and S. Grewal, "Developing organisational decision-making capability: a knowledge manager's guide," J. Knowl. Manage., vol. 15, no. 3, pp. 403-421, 2011.

[21] K.Y. Wong, L.P. Tan, C.S. Lee, and W.P. Wong. "Knowledge management performance measurement: measures, approaches, trends and future directions Information," Development, vol. 31, no. 3, pp. 239-257, 2015.

[22] MONO Project. MONO Contenidos Digitales, manejo de la integración, control y optimización de contenidos digitales. 2016. Web Site. [Online]. Available: http://wikimono.uniandes.edu.co/.

[23] G. Pedraza-Garcia, G. Beltrán, D. Correal, and O. González, "MONO+KM: Knowledge management in collaborative project development," in Computing Colombian Conference (10CCC), pp. 141-149, 2015. 
[24] M. Todorovíc, D. Petrovíc, M. Mihíc, V. Obradovíc, and S. Bushuyev, "Project success analysis framework: A knowledge-based approach in project management," Int. J. Project Manage., vol. 33, no. 4, pp. 772-783, 2015.

[25] V. Holzmann, "A meta-analysis of brokering knowledge in project management," Int. J. Project Manage., vol. 31, no. 1, pp. 2-13, 2013.

[26] L. Simon, "Managing creative projects: An empirical synthesis of activities," Int. J. Project Manage., vol. 24, no. 2, pp. 116-126, 2006.

[27] J. Moody and M. Dodgson, "Managing complex collaborative projects: Lessons from the development of a new satellite," J. Technol. Transfer, vol. 31, no. 5, pp. 568-588, 2006.

[29] D. Xinghang, M. Nada, and D. Guillaume, "Knowledge discovery in collaborative design projects," in 2014 Int. Conf. on Collaboration Technologies and Systems (CTS), pp. 330-336, 2014.

[28] D. Falessi, M. Becker, and G. Cantone. "Design decision rationale: Experiences and steps ahead towards systematic use," SIGSOFT Softw. Eng. Notes, vol. 31, no. 5, article 2, 2006.

[30] R.M. Utami and D.C. Lantu, "Development competitiveness model for small-medium enterprises among the creative industry in bandung", Procedia-Social and Behavioral Sciences, vol. 115, no. 21, pp. 305-323, 2014.

[31] J. Zheng and R. Chan, "The impact of creative industry clusters on cultural and creative industry development in Shanghai," City, Culture and Society, vol. 5, no. 1, pp. 9-22, 2014.

[32] I. Rozentale and M. Lavanga, "The universal characteristics of creative industries revisited: The case of Riga," City, Culture and Society, vol. 5, no. 2, pp. 55-64, 2014.

[33] M. Marcella and S. Rowley, "An exploration of the extent to which project management tools and techniques can be applied across creative industries through a study of their application in the fashion industry in the North East of Scotland," Int. J. Project Manage., vol. 33, no. 4, pp. 735-746, 2015.

[34] I. Moore, "Cultural and creative industries concept - a historical perspective," ProcediaSocial and Behavioral Sciences, vol. 110, pp. 738-746, 2014.

[35] R. Compesi, Video Field Production and Editing, 7th ed. Waltham, Massachusetts: Focal Press, 2006.

[36] M. Bakker, R.T. Leenders, S.M. Gabbay, J. Kratzer, and J.M.L. Engelen, "Is trust really social capital? Knowledge sharing in product development projects," The Learning Organization, vol. 13, no. 6, pp. 594-605, 2006.

[37] M. Gephart, V. Marsick, M. Van Buren, and M. Spiro, "Learning organizations come alive," Train. Dev., vol. 50, pp. 34-4, 1996.

[38] D.M. Ahmed, D. Sundaram, and S. Piramuthu. "Knowledge-based scenario management - Process and support,” Decis. Support Syst., vol. 49, no. 4, pp. 507-520, 2010.

[39] P. Bishop, A. Hines, and T. Collins, "The current state of scenario development: An overview of techniques," Foresight, vol. 9, no. 1, pp. 5-25, 2007. 
[40] D.M. Ahmed, D. Sundaram, and S. Piramuthu, "Knowledge based scenario management - Process and support," Decis. Support Syst., vol. 49, no. 4, pp. 507-520, 2010.

[41] A. Kankanhalli, A. and B. Tan, "Knowledge management metrics: A review and directions for future research," Int. J. Knowl. Manage., vol. 1, no. 2, p. 20, 2005.

[42] R. Mitchell and B. Boyle, "Knowledge creation measurement methods," Int. J. Knowl. Manage., vol. 14, no. 1, pp. 67-82, 2010.

[43] E.G. Glaser and A.L. Strauss. The Discovery of Grounded Theory: Strategies for Qualitative Research. London: Weidenfeld and Nicplson, 1967.

[44] G. Allan. "A critique of using grounded theory as a research method," Electron.J. Bus. Res. Method, vol. 2, no. 1, 2003.

[45] T.-F. Chiu, C.-F. Hong, and Y.-T. Chiu, "An experiment model of grounded theory and chance discovery for scenario exploration" in Advances in Intelligent Information and Database Systems, 2010.

[46] A.L. Strauss and J. Corbin, Basics of Qualitative Research: Techniques and Procedures for developing Grounded Theory. London: Sage, 1998.

[47] J. Lawrence and U. Tar. "The use of grounded theory technique as a practical tool for qualitative data collection and analysis," Electron. J. Bus. Res. Method, vol. 11, no. 1, pp. 29-40, 2013.

[48] J. Tyree and A. Akerman, "Architecture decisions: demystifying architecture," IEEE Softw., vol. 22, no. 2, pp. 19-27, 2005.

[49] M.Y. Chen, M.J. Huang, and Y.C. Cheng, "Measuring knowledge management performance using a competitive perspective: An empirical study," Expert Syst. Appl., vol. 36, no. 4, pp. 8449-8459, 2009.

[50] MediaWiki, "Main page." [Online], Available: https://www.mediawiki.org/wiki/MediaWiki.

[51] Semantic Media Wiki. [Online]. Available: http://semantic-mediawiki.org/.

[52] H.H. Chang, Y.C. Tsai, and Y.H. Chen, "Knowledge characteristics, implementation measures and performance in Taiwan hospital organizations," Int. J. Bus. Inform., vol. 4, no. 1, pp. 23-44, 2009.

[53] R. Erwee, B. Skadiang, and B. Roxas, "Knowledge management culture, strategy and process in Malaysian firms,” Knowl. Manage. Res. Pract., vol. 10, no. 1, pp. 89-98, 2012.

[54] K. Charmaz, Constructing Grounded Theory: A Practical Guide through Qualitative Analysis. London: Sage, 2006.

[55] W. Kunz, H.W. J. Rittel, W. Messrs, H. Dehlinger, T. Mann, and J.J. Protzen, "Issues as elements of information systems," Tech. Rep., 1970.

[56] W. Xiong, H. Lu, C. Fang, and Z. Wang, "Research and implementation of instant collaborative development for 3D animation production," in 2010 2nd Int. Workshop on Intelligent Systems and Applications (ISA), pp. 1-4, 2010. 
[57] V. Pipek, V. Wulf, and A. Johri, "Bridging artifacts and actors: Expertise sharing in organizational ecosystems," Comput. Supported Coop. Work, vol. 21, no. 2-3, pp. 261-282, 2012.

[58] M. Terzieva, "Project knowledge management: How organizations learn from experience," Procedia Technol., vol. 16, pp. 1086-1095, 2014.

[59] J. Abke, C. Gold, N. Kalberer, and M. Kuhn, "Collaborative knowledge transfer via Wiki: A project based learning approach in software engineering," in 2014 Int. Conf. on Interactive Collaborative Learning (ICL), pp. 283-288, 2014.

[60] C.H. Yang, M.Y. Wu, C.M. Lin, and D.L. Yang, "Implementation of Wiki-based knowledge management systems for small research groups," 2008 Eighth Int. Conf. on Intelligent Systems Design and Applications, vol. 2, pp. 346-349, 2008. 